\title{
PARATUBERCULOSIS: AN UPDATE
}

\author{
Lilenbaum W. ${ }^{2 *}$; Marassi C.D. ${ }^{1}$; Oelemann W.M.R. ${ }^{1}$ \\ ${ }^{1}$ Instituto de Microbiologia, Universidade Federal do Rio de Janeiro, Rio de Janeiro, RJ, Brasil; ${ }^{2}$ Laboratório de Bacteriologia \\ Veterinária, Universidade Federal Fluminense, Niterói, RJ, Brasil
}

Submitted: September 25, 2006; Returned to authors for corrections: March 29, 2007; Approved: July 29, 2007.

\section{MINI-REVIEW}

\begin{abstract}
Paratuberculosis is a chronic enteritis that affects ruminants and is caused by Mycobacterium avium paratuberculosis (Map). The disease is worldwide spread and causes important economic losses. In Brazil, the bacillus was isolated in the south and northeast regions of the country and in Rio de Janeiro, but there are no enough epidemiological studies about its occurrence. Isolation of Map from tissues or fecal samples is $100 \%$ specific, but Map shows the most fastidious growth of all mycobacteria. Incubation lasts $8-12$ weeks, with a dependency on exogenous mycobactin J. Diagnostic tests based on specific DNA sequences allow fast and secure identification, and PCR has been used to confirm positive culture results and to identify Map in feces, milk and tissues. The most frequently used target sequences are the gene encoding the 16S rRNA, and the insertion element IS900. Serological assays are widely used for the herd diagnosis of the disease. A commercial ELISA with M. phlei pre-adsorption step achieves a specificity of $95.4 \%$ to $99 \%$ and a sensitivity of about $45 \%$. Until now, there is no effective treatment for ill animals and control programs are based on managing procedures of herds and culling of symptomatic animals. In Brazil, paratuberculosis was recently identified and has been demonstrated even in autochthonous closed herds. Therefore, it is essential to perform an epidemiological national research and to investigate the economic impact of the disease in our herds. These results could promote a control program of paratuberculosis adapted to the Brazilian requirements.
\end{abstract}

Key words: Paratuberculosis, Bovine, Mycobacterium, Cattle, Map

\section{THE DISEASE}

\section{General Characteristics}

Mycobacterium avium subsp. paratuberculosis (Map) is the etiological agent of a chronic enteritis in cattle known as Johne's Disease or Paratuberculosis. Johne and Frothingam first described the disease in Germany (1895), although only in 1910, Trowt isolated the microorganism and experimentally reproduced the disease in cattle (32). Paratuberculosis is characterized by chronic intermittent diarrhea with bacillary excretion in feces. It progresses through several stages and, in the majority of cases, takes several years to manifest itself with clinical signs (48). Usually, ruminants are infected at an early age of life by ingestion of Map-contaminated milk or by contact with feces from infected herds (48). Pregnant cows with advanced disease may be able to transmit it to the fetus (8).

After an initial infection, there is a long subclinical stage without shedding of the microorganism. This stage can last for two to five years, and Map proliferates in the bowel, mesenteric lymph nodes. Alternatively, the infection can spread through the whole body. In ruminants, the focus of disease's pathology is the ileoceacal junction and the jejunal region. As in other mycobacterial diseases, granuloma formation occurs at the site of the infection, but the more common pathology is diffuse granulomatous enteritis with mucosal thickening due to large numbers of infiltrating macrophages (3).

Paratuberculosis progresses through three stages: during the first stage, animals are infected but do not show any clinical

*Corresponding Author. Mailing address: Laboratório de Bacteriologia Veterinária - Universidade Federal Fluminense - Rua Hernani Mello, 101/309 Centro - 24210-030 Niterói, RJ - Brasil. Tel.: (21) 2620-0623. E-mail: mipwalt@vm.uff.br 
signs of the disease and there in no shedding of microorganism. During the second phase, when bacterial excretion is intermittent, no characteristics signs are presented, and the herd shows productivity loss accompanied by unspecific symptoms, such as low fertility and mastitis. Finally, during the advanced stage, severe diarrhea that does not respond to treatment occurs and is related with a lower capability of the intestinal mucosa to retain nutrients. Loss of body weight, wasting and death are consequences of this intake insufficiency (11).

An intermittent and profuse diarrhea is the characteristic sign of the infection (17). In some cases, cattle can recover after support therapy, or the symptoms can disappear after some weeks without any treatment. Other studies demonstrated that stress situations, such as pregnancy, low fat diet, lactation, transportation, and worm infections could trigger the onset of the first symptoms of the infection (6).

\section{Immunologic Response}

Usually, ruminants become infected as calves by ingestion of milk, colostrum and manure contaminated by feces from infected cows (11). It is believed that M cells serve as the portal of entry for Map into the lymphatic system, since the absence of microvilli, brush-borders, digestive enzymes and surface mucus in these cells contribute to Map attachment to the cell (11). Bacteria penetrate into the cell on the apical side and leave the cell via the basallateral membrane by transcytosis. Once expelled, they are captured either by macrophages or by dendritic cells, where they reside either intact within the phagocytic cell, or may be processed and presented to T-lymphocytes (60).

Macrophages are activated and produce interleukin-1 (IL1). IL-1 and presentation of the antigen through MHC II and MHC I molecules will activate both populations of Tlymphocytes (CD4+ and CD8+, respectively). Once activated, T-lymphocytes will produce IL-2, which results in specific clonal expansion of these two cells populations (60).

Local inflammation relates to a Th- 1 immunological response characterized by the expression of pro-inflammatory cytokines, such as IFN- $\gamma$, TNF- $\alpha$, IL-1, IL-2, IL-6 e IL-12. Some of the cell wall and lipopolysacharide components in mycobacteria lower the defense mechanisms of macrophages, which destroy microorganism by the nitric acid pathway and the respiratory burst. This resistance mechanism and the multiplication of Map within macrophages are obligatory for the development of the disease. Lipoarabinomanan (LAM) on the cell wall is responsible for macrophage inactivation. The intracellular maintenance of bacteria, even in the presence of high cytokines concentration, is an important factor for the inflammatory pathology of the infection, though Map and its components do not have any toxic effect on the host (10). The extreme inflammatory response in the gastrointestinal tract against Map diminishes the nutrient intake and, consequently, leads to the nutritional decline of the infected animal.
As the bacterial multiplication evolves, there is an increase of Th-2 immunologic response, stimulating the production of IgG1. At the late stages of infection, there is a massive antibody production suppressing Th-1 cytotoxic response; nevertheless, this is not sufficient to protect the host against Map (3).

As in other mycobacterial infections, CD4+, CD $8+$ and $\gamma \delta \mathrm{T}$ cells populations are believed to be involved in protection against Map, and IFN- $\gamma$ is an essential cytokine for cell activation. $\gamma \delta \mathrm{T}$ cells appear to be important during the early response to pathogens and may provide a first line of defense, when they first interact with CD4+ T cell and then with CD8+ cells. The $\gamma \delta \mathrm{T}$ cell population represents almost $40 \%$ of the whole lymphocyte population in calves, declining to $5 \%$ of the adult bovine $\mathrm{T}$ cells. This lymphocyte subpopulation is found in epithelial surfaces, where they react with antigens presenting for MHC I or MHC II molecules. $\gamma \delta$ cells are cytotoxic for cells infected with mycobacteria and produce IFN- $\gamma$, IL-2 e TNF- $\alpha$. Its massive presence in calves is supposed to be the main reason for the long latency time of infection observed (60).

Chronic exposure to Map and the resulting proinflamatory response within the intestinal tissue of infected animal would lead to changes in gene expression patterns. Aho et al. (3) demonstrated upregulation of IL-1 in ileal tissue of cattle infected with Map due to a major intensity of gene expression for transcripts encoding this protein (3). Activated macrophages could lead an IL-1 up regulation five-fold higher than normal. This situation augmented the expression of TRAF- 1 receptors on macrophages, responsible in controlling the cellular apoptosis mechanisms. TRAF-1 associated with TRAF-2 restricted CD40, TNF- $\alpha$, IL- 1 and Faz production, regulating the cell death programmed processes (15).

The humoral response level depends on the dose of microorganism, dissemination, and the route of entry. Recently studies proposed that there is not an active switch from a proinflammatory to a predominantly $\mathrm{IgG} 1$ response, which could develop in any time of the infection, regardless the route of the infection and the microorganism amount. Simply, at the late stages of infection, there is an imbalance between cytokines level and suppressor immunologic cells, and the IgG1 production is the only inflammatory response that remains (15). At this time, infected animals became high shedders of Map by feces and positive results on serological assays are evident. In the very late stage of the disease, with all characteristics symptoms, there is an anergy due to state of wasting of the animal (33).

\section{CHARACTERISTICS OF THE MICROORGANISM}

\section{Taxonomy and Phylogenetic Analysis}

Mycobacterium avium subsp. paratuberculosis (Map) is classified as a member of the order Actinomicetales, family Mycobacteriaceae, and Mycobacterium avium-intracellulare complex. This complex comprises four species: $M$. avium avium, 
M.avium paratuberculosis (Map), M. avium silvaticum and M. avium intracellulare. This classification is based on DNA-DNA hybridization studies and taxonomic numerical analysis (28). Phenotypically, Map differs from M. avium and M. silvaticum for its mycobactin dependency, and genotipically, for the presence of 15 or 20 copies of the insertion element IS900 (6). An insertion element (IS) is a small, mobile genetic element containing genes associated with insertion functions. Its location within structural genes causes insertional mutations. The IS900 presents unique characteristics: It lacks terminal inverted repeats to form stem loop structure and no flanking direct repeats (30). Although this genetic sequence has been widely used for paratuberculosis diagnosis, IS900 was found in $M$. cookii isolated from a healthy cow. This finding suggests that IS900 PCR is not a $100 \%$ specific test $(20,21)$. Therefore, other Map-specific genetic elements were evaluated, in order to improve the PCR detection of Map. The alternative target elements included F57, ISMav 2 and Hsp X sequences. Although these markers might not be as sensitive as the multiple copy IS900 elements, they are highly specific for Map (62).

Analysis of the rRNA genes (rDNA) of mycobacteria has resulted in the division of these genes into two separate clusters. These correspond to the traditional fast-growing mycobacteria, represented by nonpathogenic environmental isolates. The second group corresponds to the slow-growing mycobacteria, containing most of the overt pathogens (32). Map is one of the most fastidious slow-growing mycobacteria. As others mycobacteria, it is an intracellular microorganism with a complex lipidic cell wall, composed most by long chain mycolic acids (13). Mycolic acids diminish permeability of the cell wall, which augment the resistance against bacteria lysis, temperature variations, and antibiotics actions (5). Some studies demonstrated that mycolic acids composing the cell wall of some species of bacteria, as Corynebacterium sp, diminish its permeability and fluidity; the mycobacteria cell wall is composed by long chains mycolic acids, which confers to this group of microbes even more resistance on environment (43) .

The size of the Map genome has been estimated to be 4.4 to $4.7 \mathrm{Mb}$. Compared to other mycobacteria, this is similar to the M. tuberculosis genome of $4.41 \mathrm{Mb}$ and the M. bovis genome of $4.4 \mathrm{Mb}$, but slightly larger than the estimated size of the genome of $M$. leprae $(3.3 \mathrm{Mb})$. Map DNA has a base composition of 66 to $67 \% \mathrm{G}+\mathrm{C}$, similar to M. tuberculosis and $M$. bovis, with $65 \%$ and $64 \%$, respectively. No endogenous plasmid DNA has been reported so far for any isolate of Map (32). Recent analysis demonstrated that the Map strain K10 possesses a genome of $5 \mathrm{Mb}$ in a circular chromosome with more than 4000 genes (8).

Depending on the region of the genome studied, a comparison between Map and M. avium, the causative agent of infection in birds and swine, shows almost $98 \%$ of homology of total DNA, and 100\% identity for the rRNA encoding genes.
This genetic similarity between two subspecies results in a huge number of common antigens that lead to cross-reactions in diagnostic tests based on immunological response. In spite of this high homology, species present different phenotypic features, based on the time of growth in culture and dependence on mycobactin (46).

When compared with other mycobacterial species, some genome regions show $99 \%$ homology, as for example the genes encoding antigens 85A, 85B and 85C (Ag85 complex). This complex shows significant similarity between Map and other mycobacteria species. The most conserved regions of this complex are related to fibronectin fixation, as described for the $\mathrm{N}$-terminal region of this Map antigen (19).

\section{Microbiology and Ecology}

Map is a $0.5 \times 1.5 \mu \mathrm{m}$ acid-fast bacillus that occurs in clumps. Cultivation of the organism is carried commonly on Herrold's egg yolk medium forming rough, non-pigmented, white, firm and glistening colonies. In spite of its easy growth in vivo, Map has a fastidious growth in culture media supplemented with mycobactin. Although the mycobactin dependence is a strong evidence for Map, it cannot yet be considered as a patognomonic feature, because $M$.avium silvaticum and some strains of $M$. avium avium also depend on mycobactin. Nevertheless, mycobactin dependence is not a stable condition for $M$. silvaticum, since it is lost over consecutive cultures. Besides, M. silvaticum grows at $\mathrm{pH} 5.5$ and is inhibited by cycloserine (5).

The alkaline phosphatase production test is negative for Map, but positive for M. avium and M. silvaticum. M. avium causes disease in chicken, rabbit and swine, while M. silvaticum causes disease only in chicken. Map is pathogenic for ruminants, and bovines represent the most frequently infected host (31).

An epidemiologic study demonstrates a narrow diversity between strains that infect ruminants. The strain specificity for two gene sequences, IS 900 and locus 251, was analyzed by fingerprinting. The analysis showed that Map samples isolated from cattle and sheep living in a same geographic region were more related than samples isolated from these same hosts living in different regions, suggesting a permutation between Map strains infecting different ruminant species (15).

Map can survive in the environment during long periods. Experimentally, the bacillus can survive for five months in clear water, nine months in shallow water, and 11 months in bovine feces. It can resist for 47 months in dry soil, or it can be frozen at $-14^{\circ} \mathrm{C}$ for at least one year. Some studies suggest that Map can survive for longer period in acid soils. Pastures must be considered as source of infection up to one year (13).

The agent is resistant to many disinfectants. Map is killed within 10 minutes after exposure to formalin (5\%), cresylic disinfectants (1:32 dilution), phenol (1:40 dilution) or sodium hypochloride (1:50 dilution) (12). The most efficient disinfectant 
for decontamination of feces are phenolic products in the presence of a high detergent concentration. The detergent improves the phenol absorption by the bacterial cell. Since Map is highly resistant to heat, pasteurization is not sufficient to kill all microorganisms in milk and its derivatives $(7,35)$.

\section{Major Antigens}

Although the exact role of different proteins and antigens in the development of the disease and the immune response it is not known, the immune response against these organisms is a combination of both humoral and cellular immunologic reactions. The analysis of mycobacterial antigens is difficult due to the extremely slow growth of the bacteria and cross-reactivity with antigens from other mycobacterial and nonmycobacterial species (22). The expression of these proteins seems to be influenced by the culture media composition and duration of cultivation. Some of them can be isolated from fresh cultures, while others can be observed in long-term cultures (26). Additionally, antigens useful for antibody detection are expressed differently (intra- and extracellulary) by different Map strains (28).

The search for Map specific antigens for diagnostic testing or vaccine development against paratuberculosis has led to the discovery of several immunogenic proteins (32). In practice, proteins carrying epitopes specific for B lymphocytes could be used to develop vaccines or serological assays, while proteins with $\mathrm{T}$ lymphocyte specific epitopes could be used in intradermal tests that are based on hypersensitivity reactions (13). In general, secreted bacterial proteins are recognized earlier by the host immune system than cytoplasmic proteins and, therefore, its use in serologic assays to detect early stages of infection was investigated. Polysacharide and glycoconjugate proteins are major antigens secreted by Map (48).

The analysis of the distribution of Map-specific proteins in culture filtrates and cellular extracts identified four distinct groups of antigenic determinants: antigens expressing specific Map epitopes, common antigens expressed by Map and the $M$. kansasii complex, epitopes expressed in a limited number of the mycobacterial species, and broadly cross-reactive epitopes found in non-mycobacterial species (48).

Forty-four antigens were identified by two-dimensional SDSPAGE. They include heat shock proteins, reductases, proteases, cytoplasmic or cell wall proteins, and several other proteins with unknown function (54). Of the 44 antigens, 27 reacted with anti-M. avium serum and 24 reacted with an anti-M. bovis serum; only 17 were Map-specific (63).

A comparison of the genomes of Map and M. avium identified 21 sequences as Map-specific. The comparison of Map and $M$. tuberculosis genomes revealed sequences present in this two organisms, but absent in M. avium. This result was unexpected in view of the high sequence similarity within mycobacteria of the M. avium complex (54).
Later on, 13 other sequences were identified as Map-specific, with eight of them being $100 \%$ conserved within 39 distinct Map isolates obtained from five different hosts. The function of the proteins encoded by these genes has to be elucidated. They might be involved in the synthesis of regulatory proteins and amminoacids or biotin. Specifically, gene MAP2963C encodes for a high molecular weight protein (875 aminoacids) associated with the cell surface (54).

Mycobacteria express on their cell surface a great variety of glycoconjugates (glycolipids and glycoproteins). Glycoconjugates such as lipoarabinomanan (LAM), glycolipids, and antigens actively secreted during growth play an important role in modulating both cellular and humoral response of the infected animal. LAM is a $42 \mathrm{kDa}$ polysaccharide anchored to the membrane and inserted in the mycobacterial cell wall. It represents a dominant immunogenic component that strongly reacts with sera from patients with tuberculosis and leprosy and with the sera from animals with paratuberculosis. Its presence on the cell wall of all of mycobacterial species determined low specificity index in ELISA which used LAM as a capture antigen $(13,26,32,48,56)$.

The 85 (a-b-c) complex, or mpb59, was first identified in species belonging to the M. tuberculosis complex $(30 \mathrm{kDa})$ and, later on, in Map (32kDa). Although they show 72.8\% similarity, they are not recognized by the same monoclonal antibodies and the $32 \mathrm{kDa}$ antigen is less stable than the $30 \mathrm{kDa}$ antigen $(6,31,58)$. Both were isolated from culture filtrates, and the $32 \mathrm{kDa}$ protein caused a strong stimulation of $\mathrm{T}$ and $\mathrm{B}$ lymphocytes, since the early stages of disease. In spite of this, the cytosolic stress proteins hsp60k and hsp65k seem to be important antigens, with immunomodulatory functions during the infection (40). Alkyl hydroperoxide reductases C and D (AhpC and $\mathrm{AhpD}$ ) are constitutively expressed Map proteins, which could be secreted in stress situations by others species of the M. avium complex (49).

A 34kDa cell wall protein is homologous to a protein from $M$. leprae. This antigen carries two B cells specific epitopes that could be useful for paratuberculosis diagnosis (48). The $35 \mathrm{kDa}$ protein was identified in Map, as in other mycobacteria, and showed high specificity with sera from paratuberculosis infected animals and patients with Chron disease (23). Depending on the culture conditions and incubation times, antigens differ in their expression profile, as determined by immunoblot with antiMap monoclonal antibodies (48). Both, the $34 \mathrm{kDa}$ and $35 \mathrm{kDa}$ proteins, reacted with sera from paratuberculosis infected cattle in clinical and subclinic stages, with no recognition of sera from cattle vaccinated with BCG (32). In a previous study, an ELISA employing the $35 \mathrm{kDa}$ antigen as capture antigen was developed. This test achieved positive results in $68 \%$ of animals presenting subclinical stages of the infection. Therefore, the $35 \mathrm{kDa}$ protein could be considered an important alternative to augment the sensitivity index of paratuberculosis diagnostic tests (23). 
Despite technological advances aiming at the discovery of new antigens, the animal biology concerned to MHC restriction of antigen recognition has not changed. In that way, immunological tests based on single specific antigens will not be sufficiently sensitive for practical application (64).

\section{EPIDEMIOLOGY}

\section{Incidence and Geographic Distribution}

Paratuberculosis was first described in 1895 by Johne and Frothingham in Europe, and its presence was subsequently reported worldwide. The disease mainly affects dairy herds, where cattle is created under confinement, which provides the conditions to propagate the infection. The disease is widely spread over Europe. In England, an epidemiologic study demonstrated that almost $17.4 \%$ of cattle have already presented some clinical sign of paratuberculosis. In Belgium, seroprevalence was estimated to be $6 \%$ by a commercial ELISA; In the Netherlands, results vary from 2.7 to $6.9 \%$ of $31-71 \%$ of the herd. In Slovenia, a two-year epidemiologic study indicated $11.59 \%$ prevalence among national cattle (57). In Denmark, a serological study of bulk-tanked milk from 900 dairy herds reported that $70 \%$ of herds tested positive for Map infection (34). In USA, almost $2.9 \%$ of dairy herd and $0.8 \%$ of beef cattle has been infected (22). Prevalence of the disease varies from $1.6 \%$ to $18 \%$ depending on the region of the country under study (35). Similar findings were described in Japan, Australia, New Zealand and some European countries. The paratuberculosis control program proposed by the Australian government reduced seroprevalence to $1 \%$ and clinical cases to $0.1 \%$ over seven years (7). In Buenos Aires, Argentina, where the disease was detected in 1985, an epidemiological investigation demonstrated a reactivity of $26.5 \%$ of beef cattle and $56 \%$ of dairy cattle (48).

In Brazil, there are few reports on the disease, which was first described in 1915 by Dupont (55). The bacillus was isolated in the south and northeast regions of the country, and in Rio de Janeiro $(17,39,52,54)$. The disease is considered rare and related to the importation of diseased animals. In an epidemiologic study performed in São Paulo, serum samples from 20 dairy herds were tested by ELISA and demonstrated $37.9 \%$ reactivity of 403 animals from $95 \%$ of the analyzed farms. In Rio de Janeiro, 45 herds were analyzed by a commercial ELISA (PARACHECK ${ }^{\circledR}$ CSL-Australia). This assay showed $18 \%$ positive results in $82 \%$ of the farms (22). In 2004, two herds located at the same geographic region presented some animals with characteristic symptoms of the infection. The analysis of these farms led to the isolation of Map from autochthonous cattle, which reinforced the presence of this microorganism in Brazil. This finding demonstrates that the disease represents an important sanitary problem and, as in other countries, can cause economic losses (54).

\section{Susceptibility}

Paratuberculosis affects several wild and domestic ruminant species, horses, and wild and laboratory rodents. Transmission occurs by ingestion of contaminated feces. As bacilli can be shed in the milk, the ingestion of colostrum and milk is the main form to infect calves. Map is more frequently isolated from colostrum than from milk of a lactating cow. Animals less than 30 days old are most susceptible to infection, and some experimental evidence suggests that cattle infected at an age of almost four months present more chances to develop clinical signs of the disease (12). There are some evidences for intrauterine transmission (14).

Approximately only $1 / 3$ of the young animals exposed to the bacillus are chronically infected, depending on the number of ingested bacilli and the defense mechanisms of the host. Ingestion of more organisms than the host defense system can support will result in infection. The exact number of bacilli required for infection is unknown, but morbidity suggests that the ingestion of relatively few organisms may cause infection. Animals infected as adults may develop less pronounced lesions.

The reason for the differences in susceptibility observed between adult animals and calves are not completely elucidated. The abundance of $\gamma \delta \mathrm{T}$ lymphocytes in cattle at a time when they are most susceptible to Map and their peculiar location in mucocutaneous tissues, which also represent the preferred point of entry for mycobacterial pathogens, is supposed to be related with the maintenance of the infection (9). Sheep and deer can become infected at any age and present clinical signs of the disease (12).

Apparently, there is no breed predisposition to paratuberculosis. In comparison to dairy heards, beef cattle generally moves freely over large areas and is less exposed to other cattle and their excrements. Thus, beef breeds usually have a lower incidence of disease.

\section{Zoonotic potential}

The zoonotic potential of the disease is not yet fully established. Thirty-five per cent of all animals presenting symptoms of the disease, and $10 \%$ of animals in the subclinic phase, shed the bacillus in the milk. Since the microorganism can resist to pasteurization, it can potentionally contaminate human populations. Map seems related to the etiology of Chron's disease as its causative agent, or one of the factors of a multietiological syndrome $(14,32,56)$.

Map can cause chronic inflammation of the intestine in a very broad range of animals including large and small ruminants, monogastrics such as dogs and pigs, and so far at least four types of sub-human primates. Map shows an intestinal tissue tropism even if experimentally administered by another route than the oral (34).

The finding that Map has been isolated from $70 \%$ of patients with Chron's disease (14) could indicate its relevant 
role in this infection. The fastidious and difficult growth of Map in culture media camouflages its real importance for this disease. In spite of this, the bacillus was isolated from tissues of 5\% of patients with Chron's disease using conventional media cultures. Nine out of ten Chron patients possess IgA, which recognized mycobacterial proteins richly expressed on Map. These proteins are responsible for a specific neural inflammation of the intestine of human patients. Moreover, 2/ 3 of patients with Chron's disease were positive for Map DNA, as shown by $I S 900$ PCR (34). Until now, this is a controversial issue because some research indicates the presence of Map in patients with Chron's disease, while other studies do not recognize Map as the etiologic agent of the disease. More detailed studies have to be performed to elucidate these evidences (32).

Infections due to non-tuberculous mycobacteria in immunocompetent individuals are usually not treatable with standard anti-tuberculous drugs. Map, however, is more susceptible to some newer drugs with some chemical modifications synthesized from Streptomyces sp., such as rifabutin and clarithromycin. These antibiotics are capable to accumulate within macrophages, where Map initially resides during animal and human infections. Positive results after using theses drugs in the treatment of Chron's disease could be considered as evidence of the infectious character of the disease and the involvement of Map in this pathology (34).

\section{DIAGNOSIS}

The paratuberculosis diagnosis is difficult, due to the low sensitivity of the tests developed so far. Available immunological and molecular assays may not identify all infected animals, and they may give a substantial number of false-positive results (14). This is particular true during the early stages of the disease, when shedding of bacilli is low and specific immunoglobulins are produced in undetectable amounts. The main problem of diagnosis is the detection of the infection in apparently healthy animals (56).

The gold-standard test is culture and isolation of Map from feces. However, Map can be isolated from milk or tissues of suspect animals. Serological and molecular assays currently have been used for their advantage of speed and practice $(62,64)$.

\section{Direct Examination}

The direct examination of feces or tissues imprints stained by the Ziehl-Neelsen method permits the visualization of the bacilli. However, simple visualization cannot differentiate Map from any environmental mycobacteria. When animals are low shedders, tissue imprints or fecal samples can also lead to falsenegative results. For these reasons, direct examination, although cheap, is not recommended for diagnosis $(7,12)$.

\section{Bacteriologic Culture}

Isolation of Map from tissues or fecal samples is a test with $100 \%$ specificity (56). Samples must be cultivated within 96 hours after collection; alternatively, they can be frozen at $-70^{\circ} \mathrm{C}$ and, after that, be thawed at $35^{\circ} \mathrm{C}$ for best conservation of the samples. Tissue culture is more sensitive than fecal culture, if samples are collected from sites of suggestive lesions (7). There is an increase of sensitivity for fecal culture if great amounts of feces are cultivated (64).

Map shows the most fastidious growth of all mycobacteria, and incubation lasts 8-12 weeks. The main feature that distinguishes this species from other mycobacteria, is its dependency on exogenous mycobactin $\mathbf{J}$, an iron-chelating substance used for in vitro cultivation. However, this important phenotypical characteristic of Map is shared by some M. avium avium strains which present this mycobactin dependence, but they grow faster than Map on artificial media (12).

The main diagnostic problem is the identification of infected, but clinically normal animals. Cultivation can identify shedder animals, which present more than 100 microorganisms per gram of feces. However, culture and isolation are slow and expensive methodologies and show only $50 \%$ sensitivity $(14,59)$. The shedding of bacilli is intermittent and it does not occur during the early stages of the disease (15). The step for sample decontamination is another problem inherent to this methodology. Feces and tissues samples have to be mixed with benzalkonium chloride or hexadecylpyridinium (HPC), to kill other contaminating bacteria. Actually, HPC is the most effective disinfectant, due to its bacteriostatic action on Map, although after prolonged exposure, Map can be killed by HPC (12). For decontamination, HPC is used at concentration varying from $0.25 \%$ to $0.9 \%$ for 16 to 24 hours during three days (10).

Various culture media can be used to cultivate Map. Herrold's egg yolk agar with mycobactin $\mathrm{J}$ is predominantly used. Other media, such as Dubos modified media, 7H9, 7H10 and 7H11 Middlebrook supplemented with mycobactin, are also effective. However, as these media are very rich and complex, cultures are frequently contaminated by fungi. A study conducted by Ristow et al. (54) proposes the establishment of a protocol for culture media for isolation of Map in Brazilian laboratories. The study demonstrated that the centrifugation of samples before cultivation on Herrold's medium was the protocol best suited for Map recovery, with less contamination of the material. It is the protocol recommended by the Office International de Epizooties (OIE).

The Bactec culture system uses a liquid broth, Bactec 12 with a nutrient source supplemented by the radioisotope ${ }^{14} \mathrm{CO}_{2}$. Bacterial growth is detected by automated equipment, the Bactec 460, after 4-7 weeks of incubation (14). The major problem of this process is its high costs and the disposal of the radioactive waste. 


\section{Histopathology}

Lesions are characterized by their diffuse and granulomatous aspect, non-necrotic, hyperemia or reactionary fibrosis. Histologically, lesions can be nodular (tuberculoid) or diffuse (lepromatous). Mucosal lamina propria is surrounded by giant macrophages. Intestinal villi are corrugated and distorted. Early lesions appear multifocal and tuberculoid, but progress and gradually coalesce to compress and obliterate intestinal crypts. Macrophages are usually filled with bacilli. Lymphocytes occur diffusely or as aggregates. At the advanced stages of infection, foci of necrosis may occur within the inflammatory infiltrate. In the lymph nodes, acid-fast bacilli are present in variable numbers, depending on the stage of infection. During subclinical and early stages, there is usually little number of bacilli. Therefore, histopathology can fail in detecting the disease because lesions are more punctual with only few giant cells or macrophages $(7,12)$.

\section{Molecular Assays}

Diagnostic tests based on specific DNA sequences of microorganisms allow fast and secure identification of slowgrowing bacilli. This strategy requests the identification of DNA sequences that occur specifically in the Map genome (14). PCR has been used to confirm positive culture results and to identify Map in feces, milk and tissues $(14,51)$. The most frequently used target sequences are the gene encoding the 16S rRNA, and the insertion element $I S 900$. Diagnostic tests targeting IS900 require three days. In contrast to diagnosis based on culture, no other assay is necessary to confirm results. In addition, regardless of the presence of other contaminating microorganisms in feces, molecular diagnosis detects specifically Map (14). The sensitivity of $I S 900$ PCR to identify Map in clinical samples (feces and tissues) is similar or a little less than that of culture. It was suggested that at least 10,000 bacilli per gram of feces are necessary to achieve positive results by PCR (12). One of the possible reasons for this low sensitivity could be the presence of inhibitory substances in feces and the difficulty to remove them. Although some authors found sensitivities varying from $3 \%$ to $23 \%$ in comparison to culture (62), Garrido et al. (25) obtained $94.1 \%$ of sensitivity using the freeze-boiling extraction methodology for DNA isolation.

\section{Assays for Cellular Immunity}

The intradermal allergic test was the very first to be utilized. In this test, a Map protein extract, johnin, is inoculated in the neck or in the anal-caudal fold of the animal. After 72 hours of the inoculation, the inoculation site is inspected visually and the hypersensitivity reaction, caused by the cellular immune response, evaluated. The occurrence of false-positive reactions represents a big problem of this test, besides the difficulty of interpretation and standardization of the results. The test cannot distinguish hypersensitivity reactions resulting from Map infection from those caused by contact or infection by M. bovis, M. avium, M. tuberculosis or Nocardia farcinius $(11,12)$.

The $\gamma$-IFN test is another assay based on the cellular immunity of the hosts. This test measures the $\gamma$-IFN production of sensitized T-cells by an immunoenzymatic assay. Infected animals produce three-fold more $\gamma$-IFN prior to shedding of the bacilli with the feces. Moreover, $\gamma$-IFN levels induced by Map antigens are higher than those induced by other bacteria (14). Nonetheless, this assay presents low specificity (44). The $\gamma$ IFN assay utilizes the same Map PPD used in intradermal tests as capture antigen $(14,35)$. A study performed in Denmark (a country free of bovine tuberculosis) demonstrated the occurrence of cross-reactions between tuberculosis and paratuberculosis in animals older than 14 months. These results suggest the need of antigen formulations that are more specific for paratuberculosis. Until then, the interpretation of the IFN- $\gamma$ test must be adjusted according to the incidence of the disease. In paratuberculosis, this test seems to be more appropriate as a support tool to evaluate young animals of a herd (38).

In Brazil, the incidence of bovine tuberculosis is high. Therefore, intradermal tests using M.bovis PPD are periodically performed and other tests, such as $\gamma$-IFN and ELISA for tuberculosis diagnosis, have been evaluated (40). Both infections, tuberculosis and paratuberculosis, are determined by mycobacterial agents, which share several protein antigens. This characteristic could lead to the occurrence of serological cross-reactions between theses species that could make the differentiation between these infections a huge problem in our country, where both infections coexist $(6,30,41)$.

\section{Serological Assays}

During Map infection, animals develop humoral and cellular immune responses, related to the stage of the disease. The tuberculous form of the disease, i.e. histopathological lesions in restricted areas of the intestinal tract of the infected animal, is associated with a strong cellular response at the early phase of the infection. Parallel to this event, B-cells proliferate and specific immunoglobulins are produced in large quantities. The lepromatous form arises at the late stages of the disease, characterized by the decline of the cellular response and the augment of the humoral immune response (12).

Serological tests are constantly improved to address the need of identifying subclinically infected animals. Anti-Map antibodies have been detected by several techniques, such as complement fixation (CF), agarose gel immunodiffusion (AGID), and enzymelinked immunosorbent assay (ELISA), the latter being the most frequently studied test for its intrinsic characteristics.

Although $\mathrm{CF}$ is a valuable test for the diagnostic confirmation of clinical cases, its standardization is difficult, and the technique showed unsatisfactory results for detecting subclinical animals. Sensitivity varied from 21 to $52 \%$, although its specificity achieved 95 to $97 \%$. In comparison to CF, AGID is 
superior for its easier performance and interpretation, with no significant difference between both sensitivity (18.9\%) and specificity (99.4\%) (33). AGID could achieve a specificity of $100 \%$, but is less sensitive than ELISA (12). ELISAs are more sensitive than CF and AGID, since they are capable of detecting antibodies at low concentrations (53).

Sensitivity and specificity of serological assays are calculated in comparison to isolation of bacilli from feces or tissues as gold standard. The sensitivity of isolation from tissue samples is not well known, but it is high when the clinical specimen is collected from a lesion characteristic for the infection (7). The isolation from feces shows low sensitivity, when each animal of the herd is considered separately (30 to 50\%), because the excretion of bacilli in detectable levels is irregular and does not occur during the early stages of the disease. Therefore, serological specificity could be underestimated with regard to specificity determined for culture (46). It is already known that for each animal with clinical disease, there are nine other animals with positive culture results, and 10 to 15 animals that could be infected at this same time, but with no signs of bacilli shedding or detectable serological reaction. Therefore, when a single clinical case is detected, it is estimated that almost $60 \%$ of the herd could be subclinically infected (58).

Although ELISA is an easy test to perform, it is not good enough to diagnose subclinic infections. In that way, positive ELISA results should not be considered as a unique criterion to indicate culling of reactive animals (43). Therefore, serological tests are not sufficient to control the disease, and are more useful as screening tests to estimate the paratuberculosis prevalence of a herd, and to monitor regions where paratuberculosis was eradicated and must be kept under control (56). In Brazil, ELISA has been recommended as a screening test for herds (23), as is already employed in other European countries, in Oceania, and in the USA.

ELISA can detect specific antibodies in blood or milk with higher sensitivity than AGID and CF. A comparative study of these three methodologies suggested a discrepancy between their ability to identify infected animals (57). This could possibly occur due to the genetic differences between animals, or because each test did not use a sufficient number immunodominant Map antigens (31). Some results demonstrated that ELISA is not a good diagnostic test for milk samples. Depending on the cut-off chosen, ELISA fails to identify positive animals when milk samples are analyzed $(36,53)$. In some cases, Map was isolated from milk samples, but ELISA was negative for the same specimen. This result suggested the occurrence of an intermittent shedding of bacilli in milk during the subclinic phase of the infection $(36,53)$.

The specificity of ELISA augmented with the introduction of a pre-adsorption step using M. phlei. This step intended to remove antibodies synthesized in response to exposure to environmental mycobacteria, which could be present in samples analyzed $(10,44,49)$. To diminish the number of false-positive reactions, preparation techniques for the capture antigen of Map and for the pre-adsortion antigens of M.phlei have to be identical (i.e., both bacterial preparations should be sonicated), leading to the exposure of similar epitopes. In addition, the adopted cut-off must be very high (17). A negative control serum with high levels of unspecific antibodies could fulfill this requirement, no matter the capture antigen preparation technique used, which could be a sonication, a precipitation, or a boiling methodology (17). A commercial ELISA with M. phlei preadsorption step achieves a specificity of $95.4 \%$ to $99 \%$ (5) and a sensitivity of about $45 \%$. ELISA expresses the result of the detected antibody levels as numeric values, allowing the classification of animals as positives, negatives, and suspects. This classification is determined by a cut-off value adopted for each test. ELISA has been considered as a fast, accurate, and cheap assay for paratuberculosis diagnosis (56).

In comparison with clinical signs and the presence of Map in feces, the performance of commercial ELISAs is affected by the stage of Map infection. ELISA is very useful for identifying shedding animals, and therefore can assist in reducing the contamination of the environment (63). ELISA sensitivity is around $15 \%$ when animals are not shedding Map in feces, while it achieves $87 \%$ in animals presenting clinical symptoms of paratuberculosis $(7,14,31)$. As the infection evolves, there is a great production of antibodies. Therefore, high antibody levels are correlated with the emergence of clinical signs (14). However, until now, it was not fully demonstrated at which point of the disease fecal culture or ELISA could first identify positive animals from an infected herd (23).

Recombinant antigens specific for Map have been studied to improve specificity of ELISA. ELISA results show great variability, based on the capture antigen chosen and the diagnostic methodology utilized for each test (23). There are only few recombinant Map-antigens that are fully characterized and used in immunologic assays. The use of these purified antigens diminishes the sensitivity of the tests; therefore, the use of an antigen panel as capture antigens could result in an excellent serological test (50).

The majority of Map-antigens purified from culture are instable; furthermore, their presence depends on the composition of the culture medium and of the incubation time. Some proteins are expressed in great amounts in fresh cultures while, others are obtained most abundantly in old ones $(26,47)$. Therefore, the immunologic response against theses antigens could also be influenced by the stage of infection. In this point of view, an immunologic response against some antigen could be detectable in one stage, while other antigen could identify other phases of the disease. It is assumed that antigens secreted by bacteria are the first to be presented to the immune system of the host, and cytoplasmic proteins later; thus, secreted proteins which could diagnose the disease in its early stages have been studied as capture antigen (4). 
Several proteins with immunogenic potential were identified, but only few of them are Map-specific, which limits their utilization as antigen. Besides, the majority of proteins are conjugated to carbohydrates or lipids; once cloned and expressed in bacterial systems, these proteins loose its three-dimensional conformation and the exposure of epitopes could be different with regard to the native protein. These characteristics influence the sensitivity of the tests (51).

With the purpose of improving the specificity, some researchers employ antigens found in mycobacteria of the tuberculosis complex, which could distinguish between the most common mycobacterial infections (6). MPB70 (MPT70) and MPB83 (MPT83) are the most frequently studied $(29,34)$. These proteins were identified in M. bovis and M. tuberculosis; both are expressed in low quantities by the $M$. bovis BCG strains Pasteur, Copenhagen and Glaxo, but are found in abundant amounts in the Brazil, Moscow, Sweden and Tokyo strains. They are poorly expressed in vitro, but they have a great immunogenic potential during infection of mice (62).

The specificity of ELISA augmented with the introduction of the M. phlei pre-adsorption step (10). However, this step cannot discriminate paratuberculosis from tuberculosis infection (51).

Immunological tests alone are not yet capable to identify subclinical animals, which need bacteriologic results $(43,61)$. Research data suggest that $80 \%$ of the infected animals seroconvert before the appearance of clinical symptoms. Seventy percent of the animals shed bacilli, and $96 \%$ could be identified by a combination of immunological assays and culture. In a control program, where ELISA could be applied every six months, $80 \%$ of infected animals could be identified without presenting signs of physical deterioration, keeping economic losses minimal for farm owners (17). Ferreira et al. (23) suggested the performance of ELISAs as screening tests for herds with suspected infection, and for the identification of subclinic animals, while AGID could be used for confirmation of infection in animals with clinical signs of the disease.

Although commercial ELISAs are broadly used for diagnosis of paratuberculosis in several countries, they are considered expensive for routine utilization in Brazil. Furthermore, they are difficult to obtain, due the importation barriers for biologic products. Therefore, the development of diagnostic methods adapted to local epidemiologic conditions that are capable to identify animals during the early stages of the disease and to differentiate paratuberculosis from any other mycobacteriosis is an imperative issue. Currently available commercial tests were developed and standardized in tuberculosis-free countries, or in countries with low incidence of this infection. The in-house PPA-ELISA (paratuberculosis protoplasmatic antigen) described by Fonseca, Ferreira and Lilenbaum (22) is a test easy to perform, and demonstrated promising results for screening and evaluation of national herds. Therefore, its optimization is being conducted in order to improve its sensitivity and to diminish the possibility of cross-reactions by antibodies against Map and M.bovis antigens.

\section{CONTROLAND PREVENTION}

Control programs for paratuberculosis show some differences between countries and regions where the infection has been already known for a long time (12). In general, farmers chose to cull animals with clinical symptoms of paratuberculosis. The eradication of the disease is a difficult goal to achieve, due low specificity and sensitivity of available diagnostic tests. The prolonged incubation time of the infection and the onset of shedding in the absence of clinical symptoms, allow the disease to spread before its successful identification (8). Until now, there is no effective treatment for ill animals; however, some synthetic drugs presented promising results in human patients with Chron's disease and could be useful in animals (32).

Control programs for paratuberculosis are based on managing procedures of herds, such as washing installations with specific disinfectants; calves must be separated from adult and infected animals. Calves should be fed with pasteurized milk from healthy cows. The only method, which can guarantee that an infected animal will not be introduced into a diseasefree herd, is to maintain a closed herd (12).

Vaccines to prevent paratuberculosis are commercially available only in some regions of North America and Europe, where economic losses are a serious issue, but the vaccine efficacy was not totally proven (38). Vaccination interferes with diagnostic of paratuberculosis and tuberculosis, causing false-positive results, which could lead the culling of healthy animals (46).

In Brazil, paratuberculosis was recently identified; although it has been considered an exotic disease related to the importation of cattle, it has been demonstrated in autochthonous closed herds (23). Therefore, it is essential to develop secure diagnostic methods for an epidemiological national research, and to investigate the economic impact of the disease in our herds. These results could promote a control program of paratuberculosis adapted to the Brazilian requirements.

\section{RESUMO}

\section{Paratuberculose: uma atualização}

A Paratuberculose é uma enterite crônica que afeta ruminantes, causada por Mycobacterium avium paratuberculosis (Map). A doença é cosmopolita e determina importantes perdas econômicas. No Brasil, o agente foi isolado nas regiões Sul e Nordeste além do Rio de Janeiro, mas não há estudos epidemiológicos suficientes sobre sua ocorrência. O isolamento de Map dos tecidos ou amostras fecais é $100 \%$ especifico, mas 
Map apresenta o crescimento mais fastidioso dentre todas as micobactérias, com período de incubação de até 8 -12 semanas, dependente de fonte exógena de micobactina J. Os testes diagnósticos baseados em seqüências especificas de DNA permitem uma identificação rápida e segura, e PCR tem sido usado para confirmar resultados de cultura positiva e para identificar Map em fezes, leite ou tecidos. O alvo mais frequentemente utilizado é o gene que codifica para o $16 \mathrm{~S}$ rRNA, e o elemento de inserção IS900. Testes sorológicos são amplamente utilizados para o diagnóstico de rebanho. Um ELISA comercial com uma etapa de pré-adsorção com $M$. phlei alcança uma especificidade de $95,4 \%$ a $99 \%$ e uma sensibilidade de cerca de $45 \%$. Até agora, não existe tratamento efetivo para animais doentes e os programas de controle são baseados em medidas de manejo e descarte dos animais sintomáticos. No Brasil, a paratuberculose foi recentemente demonstrada mesmo em rebanhos fechados e autóctones. Assim, é essencial realizar-se um inquérito epidemiológico nacional e investigar o impacto econômico da enfermidade em nossos rebanhos. Estes resultados poderiam ser utilizados para um programa de controle da paratuberculose adaptado ás necessidades de nosso país.

\section{Palavras-chave: Paratuberculose, Bovinos, Mycobacterium, Gado, Map}

\section{REFERENCES}

1. Adaska, J.M.; Anderson, R.J. (2003). Seroprevalence of Johne's disease infection in dairy cattle on California, USA. Prev. Med. Vet., 60, 255-261.

2. Aho, A.D.; McNutty; Coussens, P.M. (2003). Enhanced expression of IL-1 and TNF-alpha receptor-associated protein in ileal tissues of cattle infected with Map. Infect. Immun., 71, 6479-6486.

3. Allen, B.W. (1998). Mycobacteria: General culture methodology and safety considerations In: Tanya Parish and Neil G. Stoker (eds). Mycobacteria Protoc. - Methods Mol. Biol., USA, p.101, 1-15.

4. Amadori, M.; Lyaschenko, K.P.; Gennaro, M.L.; Pollock, J.M.; Zerbini, I. (2002). Use of recombinant proteins in antibody tests for bovine tuberculosis. Vet. Microbiol., 85, 379-389.

5. Anonymous. (2001). A Guide to Johne's Disease in Australia. Natl. Johne's Dis. Program. Australian Animal Healthy Council.

6. Bannantine, J.P.; Baecheler, E.; Zhang, Q.; Li, L.; Kapur, V. (2002). Genome scale comparison of Mycobacterium avium subsp. paratuberculosis with Mycobacterium avium subsp. avium reveal potential diagnostic sequences. J. Clin. Microbiol., 40, 1313-1310.

7. Bassey, E.O.E.; Collins, M.T. (1997). Study of T-Lymphocyte subsets of healthy and $M$. paratuberculosis infected cattle. Infect. Immun., 65, 4869-4872.

8. Bech-Nielsen, S.; Jorgensens, J.B.; Ahrens, P.; Feld, N.C. (1992) Diagnostic accuracy of $M$. phlei absorved serum ELISA for diagnosis of bovine paratuberculosis in dairy cows. J. Clin. Microbiol., 30, 613-618.

9. Clarke, J.C. (1997). The pathology and pathogenesis of paratuberculosis in ruminants and other species. J. Comp. Pathol., 116, 217-261.

10. Chiodini, R.; Van Krueningen, H.J.; Merkal, R. (1984). Ruminant paratuberculosis: the current status and future prospects. Cornell Vet., 74, 218-262.
11. Cocito, C.; Gilot, P.; Coene, M.; De Kesel, M.; Poupart, P.; Vannuffel, P. (1994). Paratuberculosis. Clin. Microbiol., 7, 328-345.

12. Collins, M.T. (1996). Diagnosis of Paratuberculosis. Vet. Clin. N. Amer.: Food animal practice, 12, 357-351.

13. Collins, M.D.; Gabric, D.M.; Lisle, G.W. (1990) Identification of two groups of Mycobacterium paratuberculosis strains by restriction endonuclease analysis and DNA hybridization. J. Clin. Microbiol., 28, 1591-1596.

14. Coussens, P.M. (2004). Model for immune responses to Mycobacterium avium subspecies paratuberculosis in cattle. Infect. Immun., 72, 3089-3096.

15. Cox, J.C.; Drane, D.P.; Jones, S.L.; Ridge, S.; Milner, A.R. (1991). Development and evaluation of a rapid ELISA test for the Diagnosis of Johne's disease in cattle. Austr. Vet., 68, 157-160.

16. Dheenadhayalan, V.; Shin, K.S.; Chang, C.F.; Chang, C.D.; Wang, S.J.; McDonough, S.; McDonough, P.; Stehman, S.; Shin, S.; Torres, A.; Chang, Y.F. (2002). Cloning and Characterization of the genes coding for antigen $85 \mathrm{~A}, 85 \mathrm{~B}, 85 \mathrm{C}$ of Mycobacterium avium subsp. paratuberculosis. DNA Sequence, 13, 287-294.

17. Driemeier, D; Cruz, C.E.F.; Gomes, M.J.P.; Corbellini, L.G.; Loretti, A.P.; Colodel, E.M. (1999). Aspectos clínicos e patológicos da paratuberculose em bovinos no Rio Grande do Sul. Pesq. Vet. Bras., 19, 109-115.

18. Dunn, J.R.; Kaneene, J.B.; Grooms, D.L.; Bolin S.R.; Bolin, C.A.; Bruning-Fann, C.S. (2005). Effects of positive results for Mycobacterium avium subsp. paratuberculosis as determined by microbial culture of feces or antibody ELISA on results of caudal fold tuberculin test and Interferon-gamma assay for tuberculosis in cattle. JAVMA, 226, 429-435

19. Englung, S.; Bölske, G.; Johnason, K-E. (2002). An IS900-like sequence found in a Mycobacterium sp. other than Mycobacterium avium subsp. paratuberculosis. FEMS Microbiol. Lett., 209, 267-271.

20. El-Zaatari, F.A.K.; Naser, S.A.; Grahan, D.Y. (1997). Characterization of a specific Mycobacterium paratuberculosis recombinant clone expressing 35000-mol weight antigen and reactivity with sera from animals with clinical and subclinical Johne's Disease. J. Clin. Microbiol., 35, 1794-1799.

21. El-Zaatari, F.A.K.; Hulten, K.; Collins, M.T.; Hucherzemeier, R.; Graham, D.Y. (2002). p35-based assay for detection of Mycobacterium avium paratuberculosis infection in cattle with Johne's Disease. Proceedings of the seventh international colloquium on paratuberculosis, section 3, Denmark, p.136-139.

22. Ferreira, R.; Fonseca, L.S.; Lilenbaum, W. (2002). Comparison between a commercial and an in-house ELISA for anti-M. avium paratuberculosis antibodies detection in dairy herds in Rio de Janeiro, Brazil. Rev. Lat. Microbiol., 44, 129-132.

23. Ferreira, R; Fonseca L.S.; Lilenbaum W. (2001). Detecção de anticorpos contra Mycobacterium paratuberculosis em rebanhos bovinos do Estado do Rio de Janeiro, Brasil. Rev. Bras. Med. Vet., 23 166-171.

24. Fifs, T.; Costopoulos, C.; Radford A.J.; Bacic, A.; Wood, P.R. (1991) Purification and characterization of major antigens from a Mycobacterium bovis culture filtrate. Infect. Immun., 59, 800-807.

25. Garrido, J.M.; Cortabarria, N.; Oguisa, J.A.; Aduriz, G.; Juste, R.A. (2000) Use of PCR method on faecal samples for diagnosis of sheep paratuberculosis. Vet. Microbiol., 77, 339-349.

26. Gasteiner, J.; Awad-Masalmeh, M.; Baumgartner, W. (2000) Mycobacterium avium subsp. paratuberculosis infection in cattle in Austria: diagnosis with culture, PCR and ELISA. Vet. Microbiol., 77, 339-349.

27. Gilot P.; Cocito, C. (1993). Comparative analysis of three sensitins used in cutaneous tests for tuberculosis and paratuberculosis in cattle. Microbiol. Lett., 110, 307-312.

28. Green, E.P.; Tizard, M.L.V.; Moss, M.T.; Thompson, J.; Winterbourne, D.J.; McFadden, J.J.; Hermon-Taylor, J. (1989). 
Sequence and characteristics of IS900, an insertion element identified in a human Chron's disease isolate of Mycobacterium paratuberculosis. Nuc. Ac. Res., 17, 9063-9073.

29. Harboe, M.; Wiker, H.G.; Ulvind, G.; Pedersen, B.; Andersen, A.B.; Hewinson, R.G.; Nagai, S. (1998). MPB70 and MPB83 as indicators of protein localization in mycobacterial cells. Infect. Immun., 66, 289-296.

30. Harry, B.N.; Barletta, R.G. (2001). Mycobacterium avium paratuberculosis in veterinary medicine. Clin. Microbiol. Rev., 14, 489-512.

31. Hietala, S.K. (1992). The options in diagnosing ruminant paratuberculosis. Vet. Med., 87, 1122-1132.

32. Hermon-Taylor, J. (2000). Mycobacterium avium paratuberculosis in the causation of Chron's Disease. W. J. Gastroenterol., 6, 630-632.

33. Johnson-Ifearulundu, Y.J.; Kaneene, J.B. (1997). Epidemiology and economic impact of subclinical Johne's disease: A review. Vet. Bull., 67, 437-447.

34. Juárez, M.D.; Torres, A.; Espitia, C. (2001). Characterization of Mycobacterium tuberculosis region containing the mpt83 and mpt70 genes. Microbiol. Lett., 203, 95-102.

35. Jungersen G.; Huda, A.; Hansen, J.J.; Lind P. (2002). Interpretation of the Gamma interferon test for diagnosis of subclinical paratuberculosis in cattle. Clin. Diagn. Lab. Immunol., 9, 453-460.

36. Klausen, J.; Huda, A.; Ekeroth, L.; Ahrens, P. (2003). Evaluation of Serum and milk ELISAs for paratuberculosis in Danish dairy cattle. Prev. Vet. Med., 58, 171-178.

37. Koets, Ad. P.; Rutten, V.P.M.G.; De Boer, M.; Bakker, D.; ValentinWeingand, P.; Van Eden, W. (2001). Differential changes in heat shock protein - LAM- and purified protein derivative $\operatorname{IgG} 1$ and $\mathrm{IgG} 2$ isotype responses during bovine paratuberculosis. Infect. Immun., 69, $1492-1498$

38. Kohler, H.; Gyra, H.; Zimmer, K.; Drager, K.G.; Burkert, B.; Lemser, B.; Hauslethener, D.; Cubler, K.; Klawonn, W.; Hrb, R.G. (2001). Immune reactions in cattle after immunization with a Mycobacterium avium paratuberculosis (Map) vaccine and implications for the diagnosis of Map and Mycobacterium bovis infections. J. Vet. Med., 48, 185-195.

39. Laranja da Fonseca, L.F.; Olival, A.A.; Pereira, C.C.; Heineman, M.B.; Richtzenham, L.J.; Santos, M.V. (2000). Identificação de anticorpos anti-Mycobacterium paratuberculosis em rebanhos leiteiros do estado de São Paulo. Arquivos da Faculdade de Veterinária UFRGS, 28, 51-60.

40. Lilenbaum, W. (2000). Atualização em Tuberculose Bovina. Uma minirevisão. Rev. Bras. Med. Vet., 22, 145-151.

41. Liu, J.; Barry, C.E.; Besra, G.S.; Nikardo, H. (1996). Mycolic acid structure determines the fluidity of the mycobacterial cell wall. $J$. Biol. Chem., 271, 29545-29551.

42. Mac Donald, W.L.; Ridge, S.E.; Hope, A.F.; Condron, R.J. (1999). Evaluation of diagnostic tests for Johne's Disease in young cattle. Austr. Vet. J., 77, 113-119.

43. McNab, W.B.; Meek, A.H.; Duncan R.J.; Brooks B.W.; Van Dreumel, A.A.; Martin S.W.; Nielsen K.H.; Sugden E.A.; Tureotte, C. (1991). An evaluation of selected screening tests for bovine paratuberculosis. Can. J. Vet. Res., 55, 252-259.

44. Manning, E.J.B.; Collins, M.T. (2001). Mycobacterium avium subsp paratuberculosis: pathogen, pathogenesis and diagnosis [Review]. Rev. Scient. Techn., 20: 133-150.

45. Muskens, J.; Barkema, H.W.; Russchen, E.; Van Maanes, K.; Schukken, Y.H.; Bakker, D. (2000) Prevalence and regional distribution of paratuberculosis in dairy herds in Netherlands. Vet. Microbiol., 77, 253-261.

46. Mutharia, L.M.; Moreno, W.; Raymond, M. (1997). Analyses of culture filtrate and cell wall associated antigens of Mycobacterium paratuberculosis with monoclonal antibodies. Infect. Immun., 65, 387-394.

47. Olsen, I.; Tryland, M.; Wilker, H.G., Reitan, L.J. (2001). AhpC, AhpD and a secreted $14 \mathrm{kDa}$ antigen from Mycobacterium avium paratuberculosis distinguish between paratuberculosis and bovine tuberculosis in an ELISA assay. Clin. Diagn. Lab. Immunol., 8: 797-801.

48. Olsen, I.; Reitan, L.J.; Holstad, G.; Wilker, H.G. (2001).Alkyl Hydroperoxide Reductases C and D are major antigens constitutively expresses by Mycobacterium avium subsp. Paratuberculosis. Infect. Immun., 68, 801-808, 2001.

49. Olsen, I.; Wilker, H.G. (1998). Diffusion blotting for rapid production of multiple identical imprints from sodium dodecyl sulfate polyacrylamide gel electrophoresis on a solid support J. Immunol. Meth., 220, 77-84.

50. Paolicchi, F.A.; Zumarraga, M.J.; Gioffre, A.; Zamorano, P.; Morsella, C.; Verna, A.; Cataldi, A.; Alifo, A.; Romano, M. (2003). Application of different methods for the diagnosis of paratuberculosis in a dairy cattle herd in Argentina. J. Vet. Med., 350, 20-26.

51. Paustian, M.L.; Amonsin, A.; Kapur, V.; Bannantinne, J. (2004). Characterization of a novel coding sequences specific to Mycobacterium avium paratuberculosis: implications to diagnosis of Johne's Disease. J. Clin. Microbiol., 42, 2675-2681.

52. Portugal, M.A.S.C.; Pimentel, J.N.; Saliba, A.M.; Baldassi, L.; Sandoval, E.F.D. (1979). Ocorrência da paratuberculose no Estado de Santa Catarina. O Biológico, 45(1-2), 19-24.

53. Reichel, M; Kittelberger, R.; Penrose, M.; Meynell, R.; Cousins, D.; Ellis, T.; Mutharia, L.; Sudgen, E.; Johns, A.; Lisle, G. (1999). Comparison of serological tests and faecal culture for the detection of Map infection in cattle and analysis of the antigens involved. Vet Microbiol., 66, 135-150.

54. Ristow, P.; Marassi, C.D.; Rodrigues, A.B.F; Oelemann, W.; Rocha, F.; Santos, A.S.O.; Carvalho, E.C.Q.; Carvalho, C.B.; Ferreira, R.; Fonseca, L.S.; Lilenbaum, W. (2007) Investigation of bovine paratuberculosis on brazilian dairy herd trough serological, bacteriological, molecular and anatomopathological tools. Vet. J., 174, 432-434.

55. Santos, J.A.; Silva, N.L. (1956). Sobre a primeira observação da paratuberculose no Brasil. Bol. Soc. Bras. Med. Vet., 24, 5-11.

56. Shin, J.S.; Yoo, H.S.; McDonough, S.P.; Chang, Y. (2004). Comparative antibody response of 5 recombinant antigens in related to bacterial shedding levels and development of serological diagnosis based on 35KDa antigen for Map. J. Vet. Sci., 5, 111-117.

57. Sockett, D.C.; Conrad, T.A.; Thomas, C.B.; Collins, T.M. (1992). Evaluation of four serological tests for bovine paratuberculosis. $J$. Clin. Microbiol., 30, 1134-1139.

58. Stabel, J.R. (2000). Transitions in Immune Response to $M$. paratuberculosis. Vet. Microbiol., 77, 465-473.

59. Tasara, T.; Stephan, R. (2005). Development of an F57-sequence based real time PCR assay for detection of Mycobacterium avium subsp. paratuberculosis in milk. Appl. Environ. Microbiol., 71, 2957-5968.

60. Vary, P.H.; Andersen, P.R.; Green, E.; Hermon-Taylos, J.; MacFaddens, J.J. (1990). Use of highly specific DNA probes and the polymerase chain reaction to detect Mycobacterium paratuberculosis in Johne's disease. J. Clin. Microbiol., 28, 933-937.

61. Walravens, K.; Marche, S.; Malbrecq, S.; Rosseels, V.; Huygen, K.; Godfrod, J. (2002). Evaluation of Lipopolyssacharides Absorbed ELISA for Serological Diagnostic of Mycobacterium avium paratuberculosis. Proceedings of the Seventh International Colloquium on Paratuberculosis, section 3, Denmark, p.184-185.

62. Waters, W.R.; Stabel, J.R.; Sacco, R.E.; Harp, J.Á.; Pesch, B.A.; Wannemuehler.(1999). Antigen specific B-cell unresponsiveness induced by chronic Mycobacterium paratuberculosis infection of cattle. Infect. Immun., 67, 1593-1598.

63. Whittington, R. (2002) An overview of paratuberculosis diagnostic tests Proceedings of the seventh international colloquium on paratuberculosis, section 3, Denmark, p.131-134.

64. Yokomizo Y.; Kishima, M.; Mori, Y.; Nishimori, K. (1991). Evaluation of ELISA in comparison with complement fixation test for the diagnosis of subclinical paratuberculosis in cattle. J. Vet. Med Sci., 53, 577-584. 